\title{
MENIMBANG INTERPRETASI HADIS RUKYAT HILAL YUSUF AL-QARADPAWI
}

\author{
Abdul Mufid \\ STAI Khozinatul Ulum Blora, Indonesia \\ Email: nawalmiza@gmail.com
}

\begin{abstract}
Muslims tend to have an adequate understanding of Islam through the Qur'an and Hadith. However, over the years, hadith has been a source of controversy in Islamic law, with the significant problem associated with understanding and determining the beginning of the bijri month. The difference is due to the various perspectives in understanding the observed crescent. This paper aims at discussing the prominent scholar, Yüsuf al-Qaradāwi in understanding the hadith in question. It argues that the impact of Yusuf al-Qaradâawi's understanding on the riyat al-hilal hadith was to unify the performance of fasting and $\overline{i d}$ al-fitr in Europe based on priority, not to unite all Moslems in the world.
\end{abstract}

Keywords: Al-Qaradāwīi, Hadith, Observation

\begin{abstract}
Abstrak: Sumber utama bagi umat Islam dalam memahami ajaran Islam adalah Alquran dan Hadis. Sepanjang sejarah Islam, hadis merupakan sumber kontroversi dalam hukum Islam. Di antara masalah yang masih hangat dan hampir sering terjadi saat ini adalah pemahaman tentang observasi bulan sabit terkait penentuan awal bulan Hijriah. Menyoal tentang perbedaan dalam menentukan awal bulan Hijriah adalah hasil dari perspektif yang berbeda untuk memahami hadis tentang pengamatan bulan sabit. Oleh karena itu, metode memahami hadis tentang "pengamatan bulan sabit" sangat mendesak untuk diteliti secara lebih mendalam. Kesimpulan akhir dari proses penelitian berbasis kepustakaan ini dapat dilihat bahwa dampak dari pemahaman Yūsuf al-Qaradāwi terhadap hadis-hadis rukyat hilal adalah harapan al-Qaradāwi untuk menyatukan puasa dan Idul Fitri di Eropa atas dasar prioritas, bukan menyatukan semua Muslim di belahan muka bumi.
\end{abstract}

Kata Kunci: Al-Qaraḍāwi, Hadis, Observasi. 


\section{Pendahuluan}

Salah satu wacana yang tetap menjadi perdebatan, terutama di Indonesia, adalah tentang rukyat hilal sebagai penentu awal Ramadan maupun Syawal. Perdebatan itu jika dilihat lebih lanjut berpangkal dari perbedaan pemahaman terhadap teks Alquran dan hadis, di antaranya hadis Kuraib tentang masalah matla' Perbedaan wacana ini tidak jarang berujung ada disharmoni antar sekte di tubuh internal Islam, setidaknya secara non-fisik, ${ }^{1}$ seperti dikatakan Ian G. Barbour, sebagaimana dikutip Amin Abdullah, bahwa telah terjadi pergumulan dikotomistik antara agama dan ilmu pengetahuan terkait hisab-rukyat sebagai metode perhitungan kalender. ${ }^{2}$

Hadis terkait wacana penentuan waktu ini menarik untuk "didudukkan" kembali sebagai upaya memahami matn maupun sanad hadis yang banyak diterima secara taken for granted. Terdapat dua term yang perlu diketahui dalam mengkaji hadis, yaitu naqd al-hadith (kritik hadis) dan figh al-hadith (pemahaman terhadap hadis). Naqd al-hadith lebih menekankan pada aspek otoritas dan validitas (kesahihan) hadis dilihat dari sisi kritik hadis, baik sanad maupun matan. ${ }^{3}$ Sementara itu fiqh al-hadith lebih menekankan pada upaya metodologi pemahaman hadis. ${ }^{4}$ Sedangkan tipologi pemahaman atas teks hadis dapat digolongkan menjadi dua: tekstual atau literal dan pemahaman konstekstual. $^{5}$

Kalangan tekstualis membatasi diri pada tradisi yang diperolehnya dari ulama klasik tanpa mempertimbangkan realitas sosial. Sedangkan pemahaman kelompok kontekstualis (yang juga disebut modernist scripturalism) tidak membatasi pada tradisi tersebut, tetapi mempertimbangkan konteks dan realitas sosial yang berada di luar teks. Dalam tipologi ini, salah satu tokoh berpengaruh adalah Yüuf

\footnotetext{
1 Ach. Mulyadi, "Melacak Geneologi Sistem dan Penerapan Mazhab Hisab Pesantren Karay Ganding Sumenep," dalam Nuansa Jurnal Penelitian Ilmu Sosial dan Keagamaan Islam, Vol. 8, No. 1 (Juni, 2011), 1.

2 Amin Abdullah, "Religion, Sicience, and Culture, An Integrated, Interconected Paradigm of Science," dalam Al-Jamiah: Journal of Islamic Studies, Vol. 52, No. 1 (2014), 179.

3 Muhammad Syuhudi Ismail, Metodologi Penelitian Hadis Nabi (Jakarta: Bulan Bintang, 1992), 28.

${ }^{4}$ Nizar Ali, Memahami Hadis Nabi: Metode dan Pendekatan (Yogyakarta: CESai YPI alRahmah, 2001), 12.

${ }^{5}$ Hasep Saputra, "Genealogi Perkembangan Studi Hadis di Indonesia," dalam Al Quds: Jurnal Studi Alquran dan Hadis, Vol. 1, No. 1 (2017), 42.
} 
al-Qaradāawi, yang beraliran kontekstualis. Dia mengupayakan pemahaman hadis dengan melihat konteks, maqāsid, dan 'illat, sehingga kesimpulan yang diambil dapat tergolong argumentatif.

Yüsuf al-Qaradâwi dinilai salah satu representasi pembaharu Islam yang spirit pemikirannya memberi titik temu antara narasi teksteks Islam dengan perkembangan zaman. Karena itu, fokus artikel ini akan mengupas serta menganalisa hadis rukyat hilal dalam paradigma Yüsuf al-Qaraḍ̄āí.

\section{Prinsip Interpretasi Yūsuf al-Qaraḍ̄āi Terhadap Hadis}

Yüuf al-Qaraḍāīi merupakan seorang pemikir kontemporer yang mengambil "sikap tengah" dalam upaya memahami hadis atau sunah. Ia meletakkan prinsip-prinsip dasar dan karakteristik serta aturan hukum yang esensial untuk memahaminya secara tepat. AlQaraḍāwi juga dianggap representasi dari kaum pembaharu yang banyak menyumbangkan pemikiran-pemikirannya bagi perkembangan Islam agar teks-teks agama dapat lebih harmonis sesuai dengan perkembangan zaman namun tidak kehilangan otentisitasnya. Pemikirannya di kalangan ulama Arab khususnya dianggap cukup kontroversial karena mereka lebih banyak menekankan pemahaman tekstual dibandingkan kontekstual. Pemikiran-pemikiran hermeneutika Yusuf al-Qaraḍ̄āì dapat dilihat dari beberapa karyanya, khususnya dalam fatwa-fatwanya. ${ }^{6}$

Ia dianggap memakai "jalan tengah" karena, di kalangan pemikir lain, marak digunakan pendekatan hermeneutika. Pemakaian istilah hermeneutika dalam kajian interpretasi pada dunia Islam adalah sesuatu yang baru dan bukan hal yang biasa dalam kesarjanaan tradisional. Tidak adanya istilah yang definitif bagi hermeneutika dalam disiplin Islam klasik. Meski demikian pemikir muslim pada dasarnya banyak yang memiliki metode hermeneutika, baik dalam arti yang sempit maupun luas, seperti al-Ghazāil, Muhammad 'Abduh, Amina Wadud, dan Fazlur Rahman. Dalam hal ini, al-Qaraḍāwi memakai pendekatan yang tetap berpijak pada tradisi klasik, dan di satu sisi menggunakan pendekatan kontemporer. Hal itu ia lakukan baik dalam memahami Alquran maupun hadis.

\footnotetext{
${ }^{6}$ Farah Nuril Izza, "Hermeneutika: Arah Baru Interpretasi Hadis (Studi Analisis Pemikiran Yüsuf al-Qardawi dalam Fatwa-fatwanya," dalam Komunika, Vol. 8, No. 2 (Desember, 2014), 194.
} 
Mayoritas umat Islam sepaham bahwa hadis sebagai pedoman hidup yang utama setelah Alquran. Dengan alasan tersebut ulama hadis banyak mencurahkan tenaga, pikiran dan waktu untuk mencari dan menyeleksi hadis-hadis yang diriwayatkan dari Rasulullah. Kegiatan penelitian hadis telah berlangsung dari masa ke masa memiliki karakteristik yang berbeda. Pendokumentasian hadis sebagai penelitian awal menemukan momentumnya pada masa pemerintahan 'Umar b. 'Abd al-'Aziz (w. $101 \mathrm{H}$ ) dengan keluarnya surat resmi untuk mengumpulkan seluruh hadis yang tersebar di wilayah-wilayah Islam. Ulama yang berhasil mendokumentasikan hadis dalam satu kitab pada waktu itu adalah al-Zuhri, seorang sarjana terkenal di wilayah Hijaz dan Syam. ${ }^{7}$

Sampai saat ini, kajian terhadap hadis Nabi masih tetap menarik untuk dilakukan meskipun tidak semarak sebagaimana yang terjadi dalam studi Alquran. Menurut Suryadi, faktor utama yang menjadi pemicu adalah kompleksitas keilmuan hadis itu sendiri, baik yang menyangkut otentisitas teks, variasi teks, maupun rentang waktu yang cukup panjang antara Nabi dalam realitas kehidupannya sampai masa kodifikasi ke dalam teks hadis. ${ }^{8}$ Karena bagaimanapun, perthatian terhadap hadis muncul belakangan setelah kodifikasi Alquran telah selesai.

Mengingat perkembangan kehidupan yang dijalani dan dihadapi umat Islam di zaman modern sangat kompleks dan sangat jauh berbeda dengan kehidupan yang dijalani pada masa-masa sebelumnya, maka kontekstualisasi hadis yang memuat penjelasan dan rincian doktrin Islam dalam berbagai bidang sangat mendesak untuk dilakukan. ${ }^{9}$

Menurut al-Qaradāwi, sunah Nabi memiliki lima karakteristik khusus, yaitu komprehensif (manhaj shumūī), seimbang (manhaj

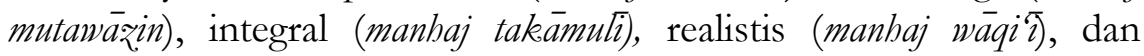
memudahkan (manhaj muyassar). Kelima karakteristik ini akan mendatangkan pemahaman yang utuh terhadap suatu hadis. ${ }^{10}$

\footnotetext{
${ }^{7}$ Ma'shum, "Metode Abu Dawud dalam Menulis Kitab al-Sunan," dalam Mutawatir: Jurnal Keilmuan Tafisr Hadith, Vol. 1, No. 2 (Desember, 2011), 180.

8 Suryadi, Dari Living Sunah ke Living Hadis dalam Metodologi Penelitian Living Qur'an dan Hadis (Yogyakarta: Teras, 2007), 89.

${ }^{9}$ Fazlur Rahman, "Perubahan Sosial Dan Sunah Awal," dalam Wacana Studi Hadis Kontemporer, ed. Hamim Ilyas dan Suryadi (Yogyakarta: Tiara Wacana, 2002), 172.

10 Yusuf al-Qaraḍāīi, Kayf Nata'ämal ma'a al-Sunnah al-Nabawiyah (Kairo: Dār alShurūq, 2004), 26.
} 
Adapun prinsip-prinsip fundamental dalam berinteraksi dengan sunah adalah sebagai berikut: ${ }^{11}$

1. Al-istisäq min thubüt al-sunnah. Meneliti dengan seksama kesahihan hadis yang dimaksud sesuai dengan acuan ilmiah yang telah ditetapkan oleh para pakar hadis yang terpercaya. Yakni, yang meliputi sanad dan matannya, baik yang berupa ucapan Nabi, perbuatannya, ataupun persetujuannya (taqrir).

2. Husn al-fahm li al-sunnah. Dapat memahami teks hadis dengan baik, sesuai dengan petunjuk bahasa, konteks hadis, sebab musabab hadis diucapkan (sabab wurūd al-haditth), dalam konteks ayat-ayat Alquran dan hadis-hadis yang lain, dalam lingkup prinsip-prinsip yang keluar dalam rangka menyampaikan risalah dan yang bukan sesuai klasifikasi yang dilakukan Syah Walìyullāh al-Dahlāwi (w. 1176 H / 1762 M). Atau dengan kata lain, meminjam terminologi Mạ̣mūd Shaltūt, antara sunah yang dimaksudkan untuk tashri (penetapan hukum agama) dan yang bukan untuk itu. ${ }^{12}$ Selain itu juga antara tashri yang memiliki sifat umum dan permanen dengan yang bersifat khusus atau sementara. Sebab di antara penyakit yang paling buruk dalam memahami sunah adalah pencampuradukan antara bagian yang satu dengan bagian lain.

3. Salamat al-nasss al-nabawì min mu'ärid aqwä. Memastikan bahwa teks matan tersebut tidak bertentangan dengan nas lainnya yang lebih kuat posisinya, baik yang berasal dari Alquran, atau hadis-hadis lain yang lebih banyak jumlahnya (mutawatir), atau lebih sahih darinya, atau lebih mendekati pokok dan lebih sesuai dengan kebijaksanaan syariat, atau tujuan umum syariat yang dinilai telah mencapai tingkat qat $\bar{i}$. Karena hal itu tidak diambil dari salah satu nash atau dua nash, melainkan dari sejumlah nash dan hukum yang saling bersatu sehingga menjadi yakin dan pasti.

Gagasan tentang hadis Yüuf al-Qaraḍāwi banyak tertuang dalam Kayf Nata'ámal ma'a al-Sunnah al-Nabawiyah Ma'älim wa Dawäbit. Rumusan tersebut akan dibahas dalam tempat selanjutnya.

11 Al-Qarad̄āwi, Kayf Nata'ämal, 43-45.

${ }^{12}$ Maksudnya sunah tashri iyah dan ghayr tashri iyah. 


\section{Memahami Hadis Sesuai Petunjuk Alquran}

Menurut al-Qaradāwi, dengan merujuk pada hadis-hadis yang sahih, ada 3 metode yang salah satunya dapat digunakan untuk menetapkan bulan Ramadan: Pertama, metode rukyat (melihat) hilal. Kedua, menyempurnakan hitungan bulan Syakban menjadi 30 hari. Ketiga, membuat perkiraan (taqdir) munculnya hilal. ${ }^{13}$

Mengenai hadis rukyat hilal, atau hadis penetapan awal bulan Hijriah, terutama tiga bulan penting yang mengandung ibadah, yakni Ramadan, Syawal, dan Zulhijah, selain telah disebutkan dalam al-kutub al-tis'ah juga diriwayatkan oleh Ibn Abi Shaybah ${ }^{14}$, Ibn Khuzaymah ${ }^{15}$, 'Abd al-Razzāq ${ }^{16}$, dan al-Bayhāīi ${ }^{17}$. Hadis-hadis tersebut menurut alGhumāri menunjukkan kewajiban berpuasa bagi seluruh umat Islam di dunia ketika hilal telah terlihat di salah satu tempat, karena perintah puasa dalam hadis tersebut bersifat 'am..$^{18}$

Sementara itu, Susiknan Azhari yang mengutip Imam Nawawi, menyatakan bahwa sabda Rasulullah di atas tidaklah mewajibkan rukyat untuk setiap orang yang hendak memulai puasa Ramadan, akan tetapi hanyalah ditujukan kepada salah seorang atau sebagian orang dari mereka. Melihat hilal cukup dilakukan oleh seorang yang adil. Demikian pendapat jumhur ulama. Pendapat lain mengharuskan dua orang yang adil. ${ }^{19}$

Terkait puasa Ramadan yang pelaksanaannya mengacu pada perintah Nabi: Berpuasalah karena melihat hilal, dan berbukalah karena melihatnya, maka sebaiknya kaum muslimin melakukan pengamatan hilal pada hari ke-29 dari bulan Syakban dengan ketentuan: pertama, apabila hilal tidak terlihat (karena terhalang awan

\footnotetext{
13 Al-Qaradāwī, Fiqh al-Siyām, 26.

${ }^{14}$ Abū Bakr b. Abì Shaybah, Musannaf Abī Shaybah, ed. Kamāl Yūsuf al-Ḥùt, vol. 2, Hadis no. 9023 (Riyad: al-Rushd, 1409 H), 284.

${ }^{15}$ Muhammad b. Ishāq b. Khuzaymah, Șaḥiḥ Ibn Khuzaymah, ed. Muhammad Muștafa 'Ażami, vol. 3, Hadis no. 1907 (Beirut: Al-Maktab al-Islāmi, 1970), 202.

16 'Abd al-Razzāq al-Ṣan`āni, Musannaf 'Abd al-Ražăq, ed. Habib al-Raḥmān 'Aẓami, vol. 4, Hadis no. 7303 (India: Al-Majlis al-Ilmi, 1403 H), 155.

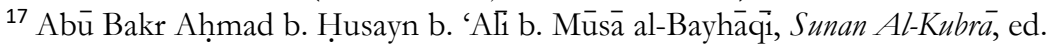
Muhammad 'Abd al-Qādir 'Ațā, vol. 4, Hadis no. 7995 (Makkah: Dar al-Baz, 1994), 251.

18 Al-Gumāri, Tawjīh al-Anz̧är li Tawhìid al-Muslimin fī al-Saum wa al-Iștär (Beirut: Dār al-Nafa'is, 1999) 34.

${ }_{19}$ Susiknan Azhari, Hisab \& Rukyat Wacana Untuk Membangun Kebersamaan di Tengah Perbedaan (Yogyakarta: Pustaka Pelajar, 2007), 56.
} 
dan lain sebagainya), maka bulan Syakban yang sedang berjalan disempurnakan menjadi 30 hari, kemudian hari berikutnya mulai berpuasa Ramadan. Kedua, diterimanya kesaksian satu orang saksi yang melihat hilal. ${ }^{20}$

Sementara itu untuk awal bulan Syawal, hilal diamati pada tanggal 29 Ramadan. Apabila banyak saksi (lebih dari satu orang) yang melihat hilal, maka wajib berbuka dan keesokan harinya terhitung 1 Syawal. Namun apabila hilal tidak teramati pada tanggal itu dengan berbagai sebab, maka hari puasanya disempurnakan menjadi 30 hari. Karena Rasulullah sendiri pernah berpuasa 30 hari dalam sebuah tahun, sementara pada tahun-tahun yang lain hanya berpuasa 29 hari. $^{21}$

\section{Al-Jam'dan al-Tarjịh terhadap Hadis-hadis yang Bertentangan}

Al-Qaradāawi beranggapan bahwa pada dasarnya tidak ada teks syariat yang saling bertentangan. Karena sebuah kebenaran tidak mungkin bertentangan dengan kebenaran lainnya. Hal tersebut hanya terjadi pada zahirnya saja, bukan hakikat sebenarnya, sehingga apabila memungkinkan untuk dilakukan kompromi, maka akan lebih baik daripada dilakukan tarjih. Karena tarjih berarti mengabaikan salah satu nas dan memakai nas yang lain. ${ }^{22}$

Pada pembahasan ini, dalam menangani teks-teks hadis yang nampaknya bertentangan, Yūufu al-Qaradāâi menawarkan dua teori, yakni al-jam" (kompromi) atau tarjih. Namun al-Qaraḍāwi dalam banyak kasus lebih condong kepada kompromi daripada tarjih.

Menurut al-Qaradāwi, hadis yang tampak bertentangan dengan hadis yang lain dapat dihilangkan pertentangannya dengan cara mengkompromikan antar hadis. Melakukan kompromi di antara hadis-hadis sahih yang kelihatannya bertentangan termasuk persoalan penting untuk memahami sunah secara tepat dan lebih utama untuk dilakukan daripada mentarjihkan. Namun demikian pengkompromian tersebut hanya berlaku pada hadis-hadis yang sahih saja. Adapun hadis yang lemah atau dipalsukan, maka tidak masuk dalam cakupan

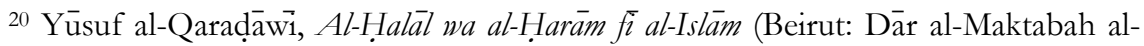
Hilāl, 1990), 311.

21 Ibid., 312.

22 Al-Qardawi, Kayf Nata'ämal, 113.
} 
kompromi. Karena hadis yang lemah maupun palsu meskipun jumlahnya banyak tidak bisa melawan hadis sahih. ${ }^{23}$

Terkait hadis-hadis rukyat hilal, nampak dari penjelasan sebelumnya, ada dua kasus hadis yang kelihatan bertentangan, yaitu: hadis tentang perintah untuk melakukan estimasi (baca: hisab) dikala langit mendung atau hilal tidak terlihat; dan hadis tentang perintah istikmäl (menyempurnakan 30 hari) bagi bulan yang sedang berjalan (baca: rukyat). Adapun penjelasannya sebagai berikut:

Pertama, hadis tentang perintah melakukan taqdir, Ismā'il menyampaikan informasi dari Ayyūb, Näfi', dan Ibn 'Umar, bahwa Rasulullah bersabda: Sesungguhnya satu bulan itu (berjumlah) 29 hari. Maka dari itu janganlah kalian berpuasa sampai melihat hilal, dan janganlah kalian berlebaran sampai melihatnya. Bila langit mendung, maka kira-kirakanlah.

Kedua, hadis di atas bertentangan dengan hadis yang memerintahkan istikmāl, yang berbunyi: Kami diberitahu 'Abd A'lā, dari Ma'mar, dari al-Zuhri, dari Abū Salamah b. 'Abd al-Raḥmān, dari Abū Hurayrah, dia berkata: Rasulullah bersabda: Apabila kalian melihat hilal, maka berpuasalah. Dan apabila kalian melihatnya, maka berlebaranlah. Bila langit mendung, maka berpuasalah 30 hari.

Hadis pertama (Ibn 'Umar) menunjukkan perintah untuk menghitung posisi hilal (estimasi) disaat hilal tidak dapat dirukyat (baca: gagal rukyat), sementara hadis kedua (Abū Hurayrah) menunjukkan perintah untuk berpuasa 30 hari bila langit mendung hingga menutup langit. Kedua hadis tersebut sama-sama bernilai sahih menurut para pensyarah kitab hadis. Karena keduanya sahih yang tampaknya bertentangan, maka al-Qaraḍ̄āi tidak memilih salah satunya (hisab saja, atau rukyat saja), namun cenderung untuk memberlakukan kompromi:

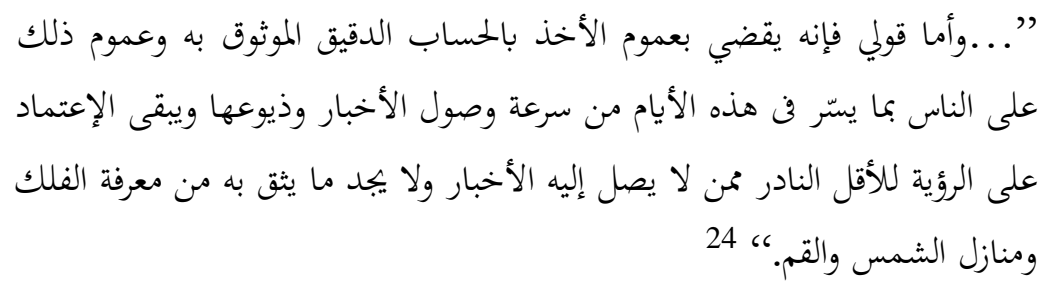

23 Yüsuf al-Qaradāwīi, Madkhāl li Dirāasat al-Sunnah al-Nabawīyah (Beirut: Dār alKutub al-'Ilmiyah, 2002),147.

24 Al-Qaraḍ̄ài, Kayf Nata'ámal, 150. 


\section{Membedakan Antara Sarana yang Berubah dan Tujuan yang Tetap}

Di antara sebab terjadinya kesalahpahaman terhadap sunah, menurut al-Qaraḍ̄āi, adalah adanya pencampuradukan antara maksud dan tujuan sunah yang sifatnya permanen dengan sarana yang sifatnya temporal dan lokal. Seseorang tidak seharusnya fokus pada sarana dan menganggapnya seakan-akan itulah yang dimaksudkan oleh sunah. Padahal orang yang mau mendalami pemahaman sunah beserta rahasia-rahasia yang terkandung di dalamnya, maka akan jelas bahwa yang penting adalah tujuan sunah. Tujuan ini sifatnya tetap dan permanen. Sementara itu sarana terkadang berubah-ubah mengikuti perubahan lingkungan, kurun waktu, kebiasaan atau faktor-faktor yang lainnya. ${ }^{25}$

Karena itu, pengkaji harus memahami sekaligus menyadari bahwa tujuan hadis adalah satu hal, sedangkan konteks yang melatarinya adalah hal lain. Sebagai contoh jika sebuah hadis menyebut sarana tertentu untuk mencapai tujuan, maka sarana tersebut tidak bersifat mengikat. Karena bisa berubah sesuai dengan perkembangan zaman dan waktu.

Membedakan antara tujuan yang tetap dan sarana yang berubahubah bermanfaat untuk membedakan antara pembacaan terhadap teks (baca: nas) secara tekstual dengan penemuan arti atau maksud di balik nas (pembacaan secara kontekstual).

Imam al-Qarā̄î (w. $684 \mathrm{H} / 1285 \mathrm{M}$ ) telah memberikan pengklasifikasian tentang kaidah maqäsid (tujuan) dan kaidah wasä̀̈l (sarana). Al-Qarā̄î mengatakan:

"Sumber hukum itu terbagi menjadi dua, yaitu maqāsid dan wasāìl. Maqāsid itu mengandung maslahat dan mafsadah. Sementara itu wasäil merupakan jalan untuk mencapai maqāsid. Sarana untuk sebaik-baik maqāsid adalah sarana yang paling baik. Sementara itu sarana yang digunakan untuk seburuk-buruk maqäsid adalah sarana yang paling buruk. Ketika maqāsid itu gugur, maka gugur pula sarana. Karena wasilah itu selalu mengikuti maqăsid dari segi hukumnya."26

Dari pernyataan al-Qarā̄i di atas, dapat disimpulkan bahwa maqsad adalah hukum-hukum yang mengandung maslahat dan

\footnotetext{
${ }^{25}$ Ibid., 139.

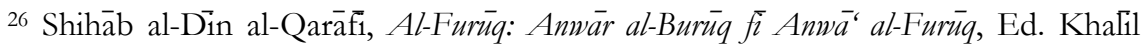
Manșūr, vol. 2 (Beirut: Dār al-Kutub al-'Tlmìyah, 1998), 61.
} 
mafsadat. Dengan kata lain, maqsad adalah hukum yang dimaksud dalam teks itu sendiri, haram atau wajib. Sementara itu wasilah adalah metode untuk menggapai maqsad. Di antara sarana tersebut ada yang berubah dari masa ke masa, dari satu tempat ke tempat lain. Penyebutan wasilah (sarana) dalam sebuah nas (Alquran maupun hadis) hanyalah menunjukkan realita saat teks diturunkan.

Ibn al-Qayyim (w. $751 \mathrm{H} / 1350 \mathrm{M}$ ) sebagaimana dikutip alQaraḍa ${ }^{-27} i^{27}$ juga telah memberikan pengklasifikasian tentang hukum syariat yang hukumnya tetap dengan yang hukumnya berubah-ubah, al-Qayyim menyatakan:

"Hukum syariat itu ada dua macam. Pertama, hukum yang tetap, dan tidak bisa berubah apapun kondisinya. Tidak terpengaruh dengan masa, tempat, maupun ijtihad ulama, seperti wajibnya beberapa bentuk kewajiban, haramnya beberapa bentuk keharaman, had yang sudah ditetapkan syariat, dan lain sebagainya. Kedua, hukum yang dapat berubah sesuai maslahatnya. Berubahnya disesuaikan dengan masa, tempat, dan keadaan. Seperti beberapa bentuk ta'zir, jenis, dan sifatnya."

Dari pernyataan Ibn al-Qayyim di atas, dapat disimpulkan bahwa sebuah hukum (fatwa) dapat berubah-ubah sesuai dengan perubahan masa, tempat, situasi, kondisi, dan niat. Yang jelas, hukum-hukum syariat hanyalah mengandung unsur menciptakan maslahat bagi umat, menegakkan keadilan di antara mereka, serta melenyapkan segala bentuk kelaliman dan kemudaratan.

Yüsuf al-Qaradāīi menyimpulkan, jika terdapat sarana lain yang lebih mudah dan dapat meminimalisir kesalahan, maka sarana tersebut dapat menggantikan sarana lama dengan tujuan yang sama. Apalagi di era perkembangan teknologi mutakhir seperti sekarang ini, banyak ilmuwan di berbagai bidang, khususnya astronomi, kemampuan manusia untuk mencapai luar angkasa dan mendarat di bulan. ${ }^{28}$

Menurutnya pula, meskipun secara tersurat memang Nabi menetapkan masuknya awal bulan dengan pemberitahuan satu saksi atau dua orang yang mengaku melihat hilal dengan mata kepala, namun perlu diketahui bahwa cara seperti itu merupakan sarana yang paling cocok untuk umat zaman sahabat. Bagaimana mungkin seseorang menolak sebuah sarana yang mencapai pada tingkatan yakin

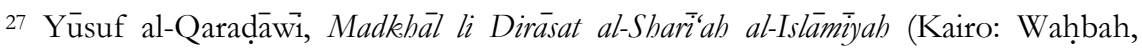
2001), 201.

28 Al-Qarḍ̄āie, Kayf Nata'ämal, 146. 
dan memberikan kepastian yang berpotensi menyatukan Muslim dari semua penjuru, serta menghilangkan perbedaan dalam berhari raya yang kadang mencapai tiga hari?

Menetapkan awal bulan dengan menggunakan hisab yang qat $\bar{i}$ pada era sekarang adalah hal yang wajib untuk diterima, termasuk dalam kategori qiyas awlawì. Maksudnya, di dalam sunah Nabi telah dinyatakan untuk mengambil sarana yang paling mudah, yaitu rukyat, padahal rukyat itu sendiri masih mengandung keragu-raguan, maka bukan berarti harus menolak sarana yang lebih sempurna untuk menggapai tujuan demi mengeluarkan umat dari perbedaan mengawali puasa yang setiap tahun menggelayutinya. Sarana yang lebih sempurna tersebut adalah sarana hisab qat $\bar{i}$.

Selain al-Qaraḍawi, ulama besar yang merekomendasikan untuk menggunakan hisab astronomi adalah seorang ahli hadis ternama, Shaykh Aḥmad Shākir. Ia berdalih, hukum rukyat yang terdapat dalam hadis itu berkaitan dengan sebuah sebab atau alasan yang juga dijelaskan dalam hadis yang lain, yaitu umat yang ummi. Dan alasan tersebut sekarang ini sudah hilang, maka sebaiknya hukum rukyat juga tidak berlaku. Sesuai sebuah kaidah: hukum itu berlaku bergantung pada alasannya dari segi ada dan tidaknya.

Lebih lanjut al-Qaradāwi menampilkan kutipan langsung dari Shaykh Aḥmad Shākir dalam karyanya Awä̀il al-Shubür al-Qamarìyah sebagai berikut:

$$
\begin{aligned}
& \text { فممّا لاشك فيه أن العرب قبل الإسلام وفي صدر الإسلام لم يكونوا يعرفون }
\end{aligned}
$$

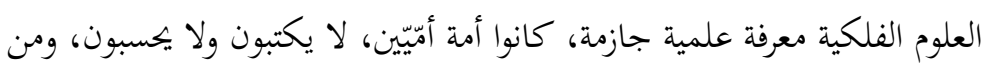

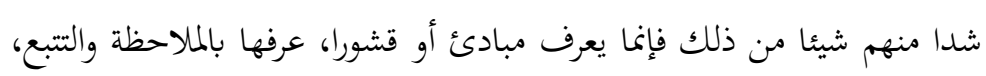

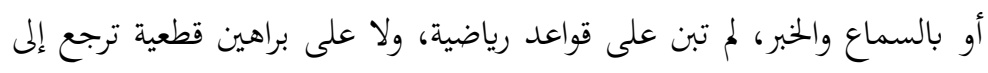

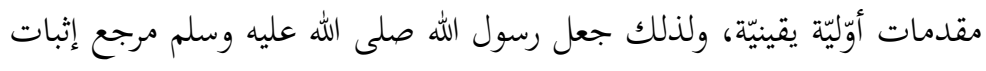

$$
\begin{aligned}
& \text { الشهر في عبادهم } \\
& \text { إلى الأمر القطعي المشاهد الذي هو في مقدور كل واحد منهم، أو في مقدور }
\end{aligned}
$$

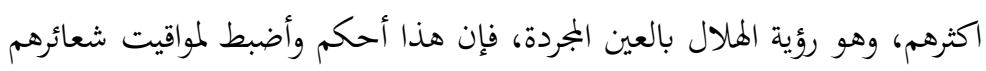

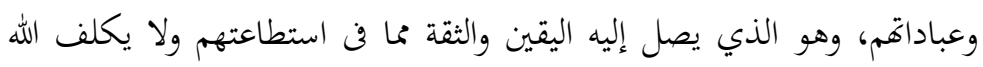

$$
\begin{aligned}
& \text { نفسا إلا وسعها. }
\end{aligned}
$$


"Pada era pra Islam dan di awal-awal Islam masuk, bangsa Arab belum mengetahui ilmu astronomi secara ilmiah. Mereka masih umat yang ummi, tidak pandai menulis dan menghitung. Mereka mengerti ayat-ayat alam hanyalah dari eksperimen kesehariannya yang tidak berpijak pada kaidah-kaidah matematis maupun buktibukti yang qat'i. Maka dari itu Rasulullah saw menuntun mereka dengan merukyat untuk menetapkan awal bulan sebagai acuan peribadatan mereka. Yang demikian itulah tindakan paling bijak dan tepat untuk mereka. Allah swt. tidak membebani hamba-Nya di atas kemampuan".

Selanjutnya pada bagian akhir pembahasan tentang wasilah dan ḩadhf, Yūsuf al-Qaraḍ̄āīi berkomentar:

$$
\begin{aligned}
& \text { وقد كنت ناديت منذ سنوات بأن نأخذ بالحساب الفلكي القطعي -على } \\
& \text { الأقل -فن النفي لا في الإثبات، تقليلا للإختلاف الشاسع الذي يحدث كل سنة } \\
& \text { فن بدء الصيام وفي عيد الفطر، إلى حد يصل إلى ثلاثة أيام بين بعض البلاد } \\
& \text { الإسلامية وبعض .ومعنى الأخذ بالحساب فن النفي أن نظل على إثبات الهلال } \\
& \text { بالرؤية وفقا لرأي الأكثرين من أهل الفقه في عصرنا، ولكن إذا نفى الحساب } \\
& \text { إمكان الرؤية وقال إها غير ممكنة لأن الهلال لم يولد أصلا فن أيّ مكان من العالم } \\
& \text { الإسلامي، كان الواجب ألاّ تقبل شهادة الشهود بحال، لأنّ الواقع الذي } \\
& \text { أثتهالعلم الرياضي القطعي يكذبم .بل في هذه الحالة لا يطلب ترائي الهلال من } \\
& \text { الناس أصلا، ولا تفتح المحاكم الشرعية ولا دور الفتوى أو الشؤون الدينية أبوابها } \\
& \text { لمن يريد أن يدلي بشهادة عن رؤية الهالال، انتهي. }
\end{aligned}
$$

"Untuk meminimalisir perselisihan yang hampir menyebar luas pada setiap tahun di saat menetapkan awal Ramadan dan Idul Fitri, dimana perselisihan tersebut berlangsung mencapai tiga hari antara sebagian negara Islam dengan negara Islam yang lain, maka sejak beberapa tahun yang lalu saya sebenarnya telah menyeru agar kita menggunakan ilmu hisab dan falak yang bersifat qat ${ }^{4}$, minimal dalam penafian dan bukan dalam penetapan. Adapun yang dimaksud penggunaan hisab dalam penafian adalah kita tetap memprioritaskan penentuan hilal melalui rukyat sesuai pendapat mayoritas ulama fikih saat ini. Namun jika hisab menafikan kemungkinan terjadinya rukyat karena hilal memang belum wujud sama sekali (atau sudah wujud tetapi belum mencapai derajat ketinggian yang memungkinkan untuk dirukyat) di tempat manapun di dunia Islam, maka dalam kondisi seperti itu wajib 
menolak kesaksian para saksi. Karena fakta yang dikukuhkan oleh perhitungan hisab qat $\bar{i}$ mendustakan mereka. Bahkan dalam kondisi ini, sebenarnya tidak perlu lagi ada upaya rukyat hilal. Begitu juga pengadilan-pengadilan agama, lembaga-lembaga fatwa, dan departemen agama tidak perlu membuka kesempatan bagi yang ingin dan akan memberikan kesaksian rukyat hilal."

Dalam karyanya yang lain, al-Qaradāwi menyatakan:

$$
\begin{aligned}
& \text { أليس من الأولى متى ما كانت هناك وسيلة أيسر فن التطبيق وأقدر على تحقيق الهدف }
\end{aligned}
$$

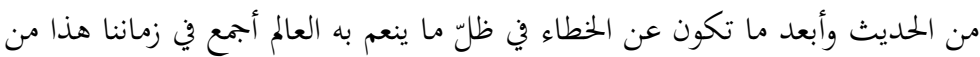

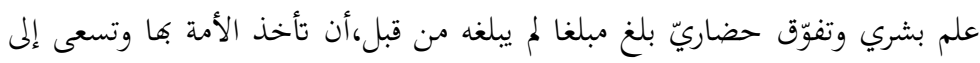

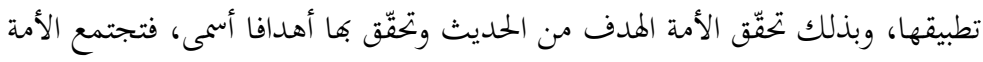

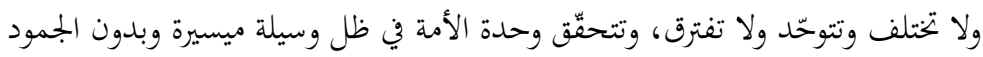

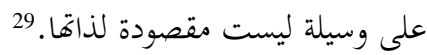

\section{Analisa atas Pemikiran Yūsuf al-Qaraḍ̄āì dalam Penetapan Awal Bulan Hijriah}

\section{Analisa dari Perspektif Studi Hadis}

Saat mengevaluasi hadis, perlu mempertimbangkan berbagai hal, seperti memahami maksud Nabi, alasan mengapa hadis itu diceritakan, memahami keanggunan sastra yang digunakan; perumpamaan, perbandingan, dan metafora. Selain itu perlu juga diperhatikan untuk menyelidiki semua perkataan Nabi secara keseluruhan. Namun yang paling penting di antara semuanya adalah mengevaluasi semua perkataan Nabi dari sudut pandang Alquran. ${ }^{30}$

Setelah menggunakan semua teknis di atas, langkah berikutnya adalah berusaha keras untuk mengaplikasikan hadis ke dalam situasi saat ini. Prinsip-prinsip di atas harus digunakan saat mengevaluasi hadis-hadis tentang rukyat hilal, sehingga dapat menentukan waktu yang tepat atas masuknya awal Ramadan dan Syawal. Semua varian sanad dan matan hadis secara keseluruhan harus dipertimbangkan supaya dapat mengidentifikasi metode terbaik untuk menentukan waktu mulai dan mengakhiri Ramadan dan lebaran.

\footnotetext{
29 Yùsuf al-Qaradāwīi, Al-Fatâwā al-Mu'ạsirah, vol. 2 (Beirut: al-Maktab al-Islāmi, 2003), 712.

${ }^{30}$ Mustafa Karatas, "Rereading the Hadith From the Perspective of Observing the Crescent”, dalam Ataturk Universitesi Sosyal Bilimler Enstitusu Dergisi, (2012), 85-93.
} 
Yüuf al-Qaraḍawi ketika membahas tentang hadis rukyat hilal, ia hanya menampilkan dua hadis saja. Pertama, hadis yang diriwayatkan oleh Abū Hurayrah. Hadis ini diberi label oleh al-Qaradāai $\bar{i}$ dengan sebutan "muttafaq 'alayb" 31 yang berarti bahwa hadis tersebut terdokumentasikan dalam dua kitab induk: al-Bukharì dan Muslim. Bunyi hadisnya lengkap dengan silsilah sanadnya adalah sebagai berikut:

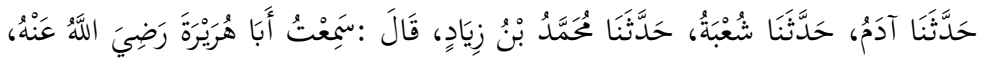

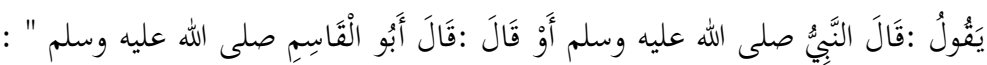

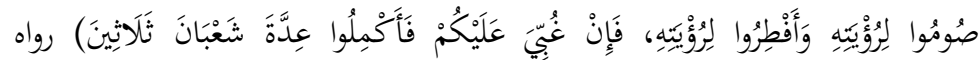

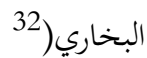

Namun setelah melakukan penelusuran ke dalam Șabịh Muslim, penulis tidak mendapati redaksi yang sama persis dengan redaksi seperti di atas, melainkan terdapat redaksi yang agak mirip dengannya. Bunyi teks matannya lengkap dengan silsilah sanadnya adalah sebagai berikut:

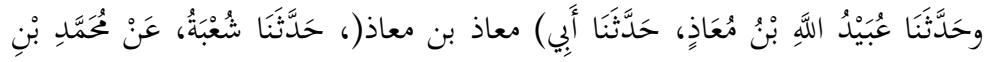

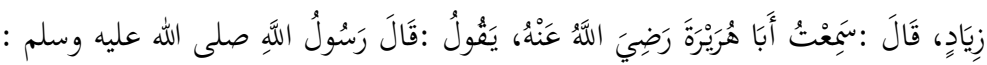

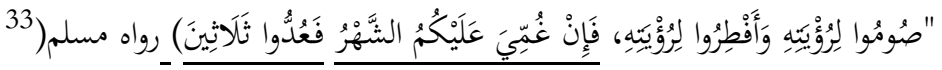

Kedua hadis di atas (yang diklaim al-Qaraḍ̄āìi sebagai muttafaq 'alayh) sama-sama diriwayatkan oleh Muhammad b. Ziyād yang diperolehnya dari Abū Hurayrah. Melalui Muhammad b. Ziyād, hadis tersebut disampaikan kepada Shu'bah. Bermula dari Shu'bah inilah matan hadis mulai berubah. Terlihat seperti hadis di atas, bahwa

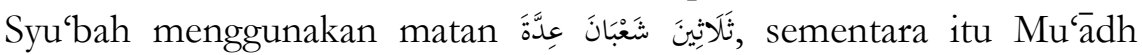

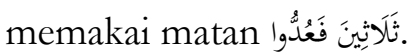

Hadis kedua yang ditampilkan al-Qaraḍ̄āi adalah hadis yang diriwayatkan 'Abdullāh b. 'Umar dan terdokumentasikan dalam Sahị

31 Yüsuf Al-Qaradāāiè, Taysìr al-Figh li al-Muslim al-Mu'ạsir (Beirut: Mu'assasat alRisālah, 2001), 26.

32 Muḥammad b. Ismāīil al-Bukhāri, Șahịh al-Bukhāri, ed. Muhammad b. Zuhayr Nașir al-Nașir (t.tp: Dar Ṭawq al-Najah, 1422), Hadis no. 1810.

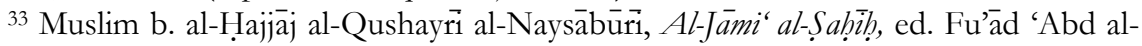
Bāqii (Cairo: Dār Ihyā' al-Kutub al-'Arabìyah), Hadis no. 1081. 
al-Bukharì. Bunyi hadisnya lengkap dengan silsilah sanadnya adalah sebagai berikut:

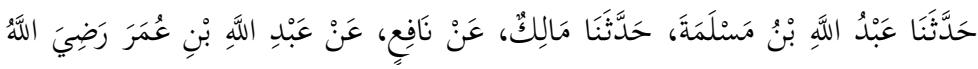

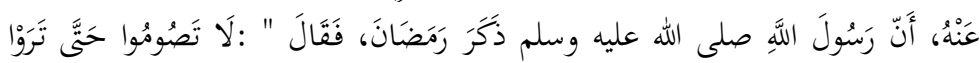

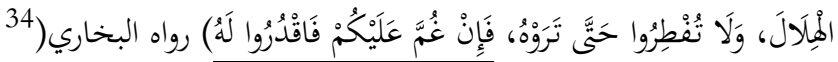

Hadis Ibn 'Umar ini juga diklaim al-Qaradāâi sebagai hadis yang muttafaq 'alayh. Namun setelah penulis melakukan pengecekan ke dalam S Sabih Muslim, penulis tidak mendapatkan teks matan yang sama persis, melainkan ada sedikit perbedaan. Bunyi teks hadisnya adalah sebagai berikut:

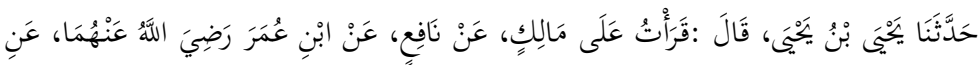

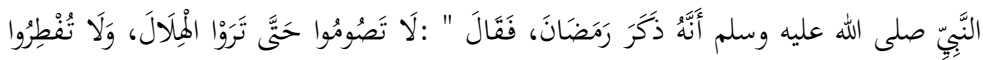

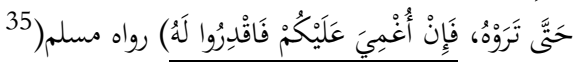

Kedua hadis di atas sama-sama diriwayatkan oleh 'Abdullāh b. 'Umar yang telah mengajarkan hadisnya kepada Näfi'. Melalui Näfi' hadis ini diteruskan kepada Mālik b. Anas. Berawal dari Mālik inilah terjadi perbedaan matan. Perbedaan kecil terletak pada Mālik 'Abdullāh b. Maslamah dengan matan ghumma (riwayat al-Bukhāri), sementara itu pada Mālik - Yahyāa b. Yaḥyā memakai matan ughmiya (riwayat Muslim).

\section{Kritik Matan}

Hadis pertama riwayat Abū Hurayrah yang dikutip al-Qaraḍawi dari Șahīh al-Bukhäri sebenarnya menuai banyak kritikan dari para ulama. Di antaranya adalah al-Ismāi ili yang dalam Mustakbraj 'alā alSahịha berpendapat bahwa Imam al-Bukhāri telah melakukan tafarrud dari gurunya, yakni Adam b. 'Iyās, dari Shu'bah. Argumentasi alIsmá'ili menyebutkan bahwa ia telah meriwayatkan hadis tersebut dari Gandar, 'Abd al-Raḥman b. Mahdi, Ibn 'Ulayyah, 'Isā b. Yūnus, Shabah, 'Așim b. 'Ali, al-Naḍr b. Shumayl, dan Yazìd b. Hārūn, yang kesemuanya telah menerima hadis dari Shu'bah. Semua perawi tersebut tidak ada yang menyebutkan fa akmilu 'iddat sha'bān thalathina yawman, melainkan menyebutkan matan fa in ghumma 'alaykum fa 'uddu

\footnotetext{
34 Al-Bukhāri, Saḅị̧ al-Bukhāri, Hadis no. 1801.

${ }^{35}$ Muslim, Al-Jämi al-Saḅih, Hadis no. 1080.
} 
thalathin. Oleh karena itu terdapat kemungkinan Adam telah meriwayatkan hadis dengan penafsirannya sendiri. ${ }^{36}$

Pandangan al-'Ismáa'ili> tersebut diamini oleh al-Hafiz Ibn $\mathrm{H}\{$ ajar dalam karyanya Fath\} al-Bäri. Menurut Ibn $\mathrm{H}$ \{ajar, pandangan al-'Ismāili> adalah benar. Karena al-Bayhaqi> sendiri telah meriwayatkan hadis tersebut dari jalur Ibra $>$ hi $>\mathrm{m}$ b. Yazid dari Adam dengan memakai redaksi:

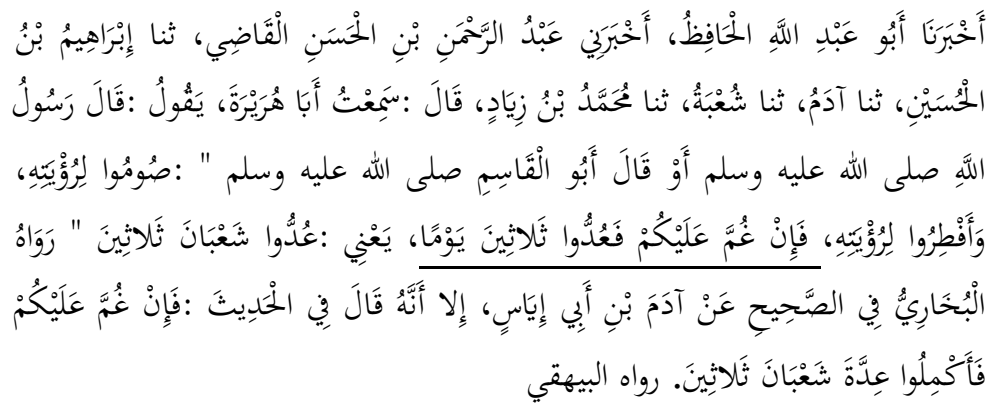

Oleh karena itu, dari matan di atas ditengarai bahwa al-Bukhāri telah menyisipkan penafsirannya pada hadis tersebut. Dengan demikian, apabila di dalam Șahịh al-Bukbäri saja masih terjadi kesalahan, padahal ia terkenal dengan hafalan dan keilmuannya, lantas bagaimana dengan hadis-hadis yang terdapat di dalam koleksi selain Sahīh al-Bukharr? Imam al-Bukhärì saja atau gurunya masih menyangka bahwa yang dimaksud adalah شَعْبَانَ عِدَّة (hitungan bulan Syakban) sehingga sangkaan itu dimasukkan ke dalam matan hadis. Padahal penambahan teks شَعَبَْانَ عِدَّة berpengaruh pada perubahan hukum.

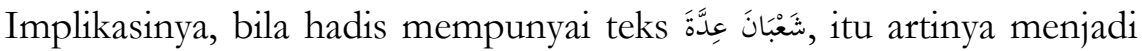
hujjah bagi Hanābilah yang mewajibkan puasa pada hari yang diragukan (syak), sementara itu al-Bukhäri sendiri memandang haram berpuasa di hari syak.

Senada dengan pandangan Muhammad b. Șadiq al-Ghumari, Zulfikar 'Ali Shah juga berpendapat adanya sejumlah problema yang ada di dalam frasa hadis-hadis tentang menyempurnakan bilangan (baca: istikmā̄). Problema itu di antaranya adalah:

Pertama, adanya perbedaan redaksi matan dalam hadis riwayat al-Bukhāri dan riwayat Muslim sebagaimana bunyi hadis di bawah ini:

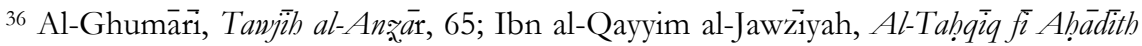
al-Khilāf, vol. 2 (Beirut: Dār al-Kutub al-'Ilmìah, 1994), 73-74.
} 


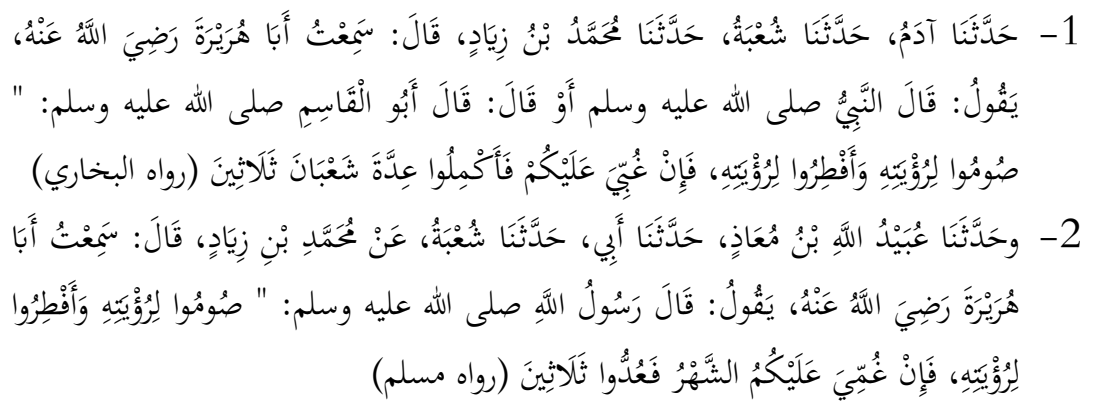

Kedua hadis di atas memiliki dua frasa. Frasa pertama tentang perintah berpuasa dan berlebaran setelah melihat hilal. Frasa kedua tentang istikmāl dikala mendung atau hilal tidak terlihat. Frasa pertama rata-rata bermatan sama dalam hadis-hadis tentang puasa. Namun problema muncul dari frasa kedua, yaitu frasa tentang istikmāl. Nampak dari beberapa hadis tentang istikmāl, para perawi, baik melalui satu jalur periwayatan maupun melalui beberapa jalur periwayatan, telah menambahkan penjelasan-penjelasan pribadi ke dalam hadis. Mereka (baca: para perawi) tidak mencukupkan berhenti hanya pada matan asli dari Nabi.

Kedua, hadis riwayat al-Bukhāri dan riwayat Muslim di atas samasama diriwayatkan melalui jalur Abū Hurayrah dari Muhammad b. Ziyād. Frasa pertama antara matan al-Bukhāri dan matan Muslim adalah sama, namun frasa kedua berbeda. Matan al-Bukhāri menggunakan kata gbubbiya, sementara itu matan Muslim memakai kata gbummiya. Kedua kata kerja tersebut memiliki arti yang sedikit berbeda. ${ }^{37}$

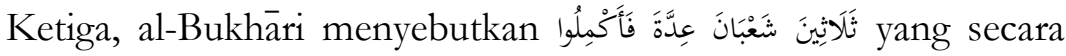
jelas menunjukkan istikmäl 30 hari untuk bulan Syakban. Sementara

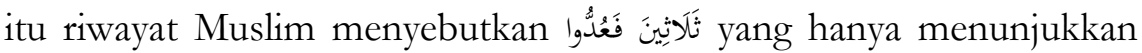
perintah menghitung bulan yang sedang berjalan menjadi 30 hari. Selain itu di satu sisi terdapat sebagian hadis yang menunjukkan perintah istikmāl bulan Syakban, dan di sisi lain terdapat pula hadis yang memerintahkan istikmäl bulan Ramadan.

37 Kata ghummiya, ghumma, ughmiya maknanya mendung yang menutupi hilal. Sementara itu ghubba, ghubbiya, ughbiya maknanya sesuatu yang samar, yakni sesuatu yang bisa membuat samar (menghalangi pandangan) ketika pengamatan hilal, antara lain bangunan, perbukitan, penguapan air, debu-debu di udara dan lain sebagainya yang bisa menghalangi observasi hilal, di samping juga mendung. Lihat Muhammad b. Manzur, Lisān al-'Arab (Kairo: Dār al-Ma árif, 1119 H), 3302 dan 3212. 
Keempat, terdapat tambahan penafsiran dari perawi seperti yang terdapat pada hadis koleksi Imam Aḥmad b. Hanbal. Bunyi hadisnya adalah sebagai berikut:

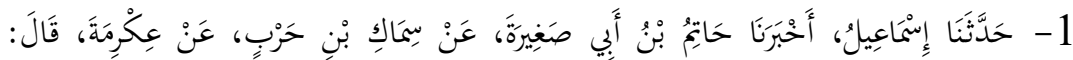

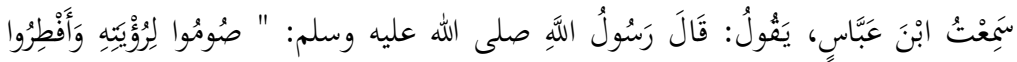

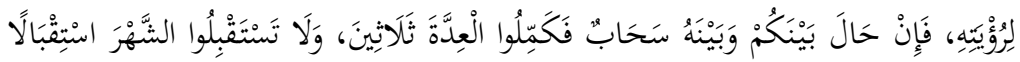

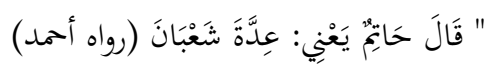

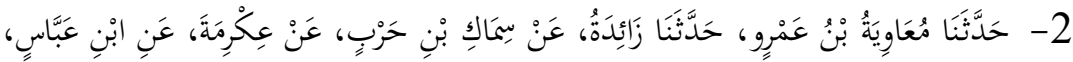

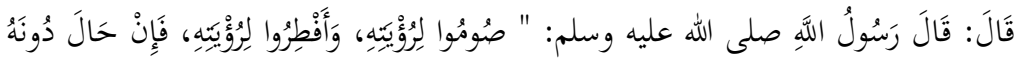

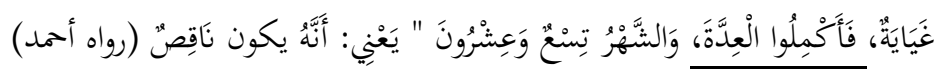

Nampak dari kedua hadis Imam Ahmad di atas terdapat

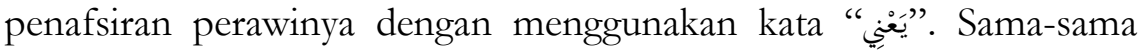
berasal dari riwayat Ibn 'Abbās, sebagaimana terlihat pada hadis di atas, Imam Aḥmad menampilkan silsilah sanad dari Simāk b. Harb dari 'Ikrimah. Lagi-lagi perbedaan bunyi frasa terjadi di sini, bahkan perbedaannya kian jauh. Frasa kedua dari hadis pertama berbunyi:

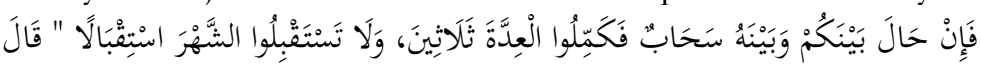

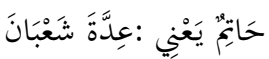

Sementara itu frasa kedua dari hadis kedua berbunyi:

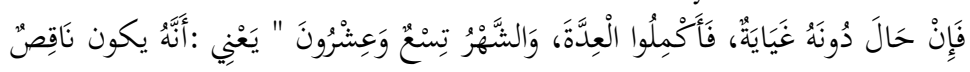

Kelima, di tempat yang lain pula, Imam Aḥmad menampilkan tiga hadis yang berbeda-beda, padahal berasal dari perawi yang sama, yakni Abu Hurayrah. Bunyi hadisnya adalah sebagai berikut:

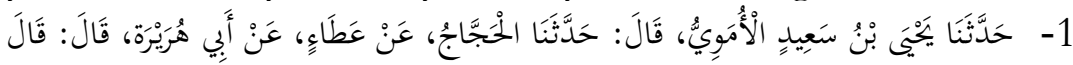

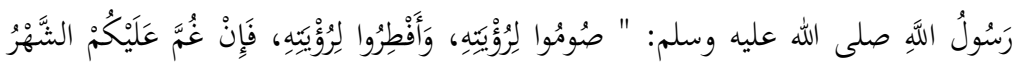

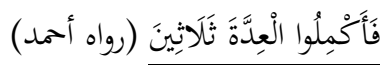

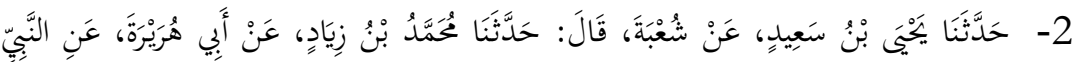

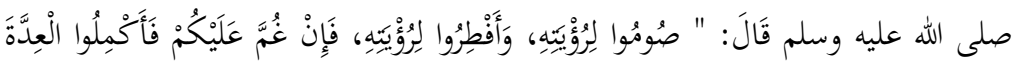

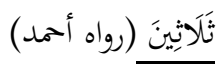




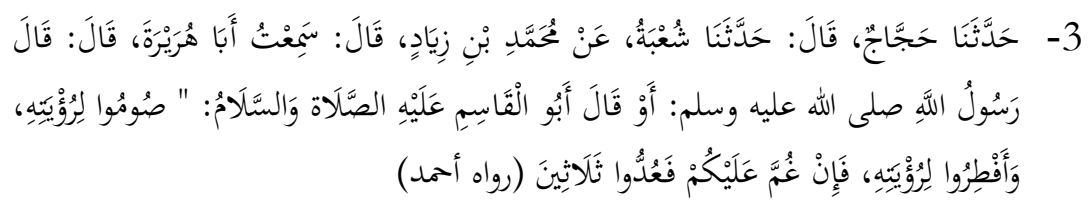

Ketiga hadis di atas terkoleksi dalam Musnad Imam Aḥmad dengan perawi Abū Hurayrah. Dua hadis berasal dari jalur Muḥammad b. Ziyād, dan satu hadis berasal dari jalur 'Atā'. Penting untuk disebutkan di sini bahwa frasa kedua dari ketiga hadis di atas berbeda jauh dengan matan koleksi al-Bukhāri yang juga menampilkan perawi Abū Hurayrah dari Muhammad b. Ziyād.

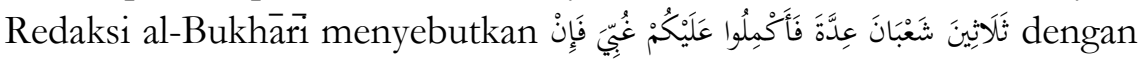
memakai kata kerja ghubbiya, sementara itu redaksi Imam Aḥmad dengan memakai kata kerja ghumma. Selain itu redaksi Imam al-

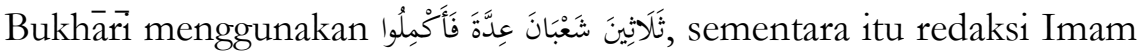

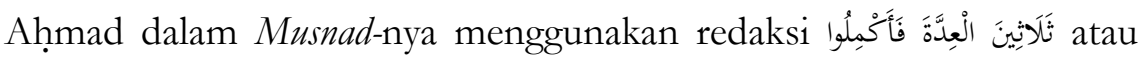

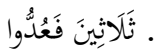

\section{Analisis Astronomi}

Sebagaimana dijelaskan dalam Kayf Nata'amal ma'a al-Sunnah alNabawìyah, yang diuraikan di atas, bahwa al-Qarad̄āīi mendukung penuh penggunaan hisab kontemporer dalam menentukan masuknya awal bulan Kamariah, yang juga diharapkan dengan hisab tersebut dalam menyatukan ibadah puasa Ramadan semua umat Islam. Hanya saja al-Qaradāâi masih tetap mengharuskan melakukan rukyat pada tanggal 29.

Berpijak pada analisis astronomi, sebenarnya pandangan alQaradââi tentang hisab rukyat sudah hampir sesuai dengan keinginan ilmu astronomi, yakni hisab imkān al-ru'yah (visibilitas hilal). Namun bila dihadapkan pada tataran pandangannya yang harus merukyat inilah yang akan menghambat cita-cita al-Qaraḍ̄āi untuk menyatukan umat. Karena rukyat itu sendiri pada zaman modern ini sudah tidak bisa lagi dipertahankan lantaran akan menimbulkan banyak masalah serius: ${ }^{38}$

Pertama, problem puasa Arafah. Menurut Syamsul Anwar, merupakan sebuah kenyataan alam bahwa rukyat itu terbatas liputannya dan tidak mengkaver seluruh permukaan bumi, sehingga

\footnotetext{
38 Syamsul Anwar, "Metode Usul Fikih untuk Kontekstualisasi Pemahaman Hadishadis Rukyat," dalam Jurnal Tarjih, Vol. 11, No. 1 (2013), 114.
} 
pada saat visibilitas pertama ada bagian muka bumi yang dapat melihat hilal, ada bagian lain yang belum dapat melihatnya. Akibatnya bagian yang dapat melihat hilal pada suatu sore akan memasuki bulan baru keesokan harinya, sementara bagian yang belum dapat melihatnya harus menunda memasukibulan baru dan baru akan memasukinya lusa, sehingga terjadilah perbedaan awal bulan. Apabila ini terjadi pada bulan Zulhijah, maka akan timbul masalah kapan melaksanakan puasa sunah Arafah bagi kawasan yang tanggal 9 Zulhijahnya jatuh berbeda dengan tanggal 9 Zulhijah di Arab Saudi yang diakibatkan perbedaan rukyat. ${ }^{39}$

Kedua, rukyat berpotensi akibatkan puasa Ramadan 28 hari. Bila mengacu kepada hadis Nabi, maka tidak mungkin suatu bulan Kamariah berjumlah 28 hari. Ketiga, penggunaan rukyat tidak memungkinkan kita meramalkan tanggal jauh hari ke depan karena kepastian tanggal baru diketahui sehari sebelum bulan baru pada setiap bulan. Begitu pula kita tidak bisa menghitung tanggal mundur ke belakang secara tepat karena tanggal di masa lalu tidak didasarkan kepada logika matematis perhitungan, melainkan ditentukan oleh kenyataan pada hari apa rukyat secara faktual terjadi.

Keempat, penggunaan rukyat sebagai metode penetapan awal bulan kamariah tidak memungkinkan umat Islam membuat suatu sistem penanggalan Islam unifikatif karena keterbatasan cakupan rukyat di muka bumi. Salah satu akibatnya umat Islam di seluruh dunia tidak dapat menyatukan momen-momen keagamaan mereka secara serentak dalam hari yang sama.

Kelima, rukyat juga problem bagi umat Islam yang bermukin di kawasan lintang tinggi, yaitu di atas $60^{\circ} \mathrm{LU}$ dan LS. Apalagi di daerah Lingkaran Kutub Utara (Arktika) di mana malam lebih dari 24 jam pada musim dingin dan siang lebih dari 24 jam pada musim panas. Semakin lebih ke utara di kawasan ini semakin bulan terlambat munculnya, bisa mencapai satu minggu setelah muncul di daerah normal..$^{40}$

Beberapa kenyataan di atas menunjukkan bahwa metode rukyat tidak dapat dipertahankan lagi karena tidak bisa memberikan suatu penandaan waktu yang pasti dan komprehensif. Oleh sebab itu tidak

39 Syamsul Anwar, "Problem Penggunaan Rukyat," dalam Rida, dkk., Hisab Bulan Kamariah: Tinjauan Syar'i tentang Penetapan Awal Ramadlan, Syawwal dan Dzulhijah (Yogyakarta: Suara Muhammadiyah, 2012), 6-7.

40 Syamsul Anwar, "Metode Penetapan Awal Bulan Qamariah," dalam Analytica Islamica, Vol. 1, No. 1 (2012), 35. 
dapat memanage waktu pelaksanaan ibadah umat Islam secara selaras di seluruh dunia. Mengenai pandangan al-Qaradāwi yang tetap berpegang pada rukyat meskipun berbasis hisab imkān al-ru'yah, bila ditelusuri dalam karyanya, maka menunjukkan kepiawaiannya dalam memformulasikan ulang pandangan para ulama brilian yang mendahuluinya. Sebut saja nama Ibn Surayj. Al-Qaradāāi mengadopsi pendapat Ibn Surayj dalam hal hisab imkān al-ru'yah, tetapi tidak mengadopsi sepenuhnya, melainkan melalui reformulasi pandangan. Adapun mengenai pandangan al-Qarad̄āi $\bar{i}$ tentang rukyat, maka ia berpegang teguh pada pandangan jumhur ulama.

\section{Penutup}

Sebuah pemikiran apapun namanya tentu tidak ada yang memiliki kebenaran mutlak. Termasuk dalam hal ini adalah teori pemahaman hadis Yüsuf al-Qaraḍāwi, terdapat kekurangan dan kelebihan. Menyoal tentang keunggulan dan kelemahan berarti menimbang metode Yüuf al-Qaraḍāwi sekaligus metode yang ditawarkan ulama lain sebelumnya. hal ini menuntut pembacaan referensi sebanyak mungkin sehingga diharapkan hasil yang disimpulkan dapat obyektif atau paling tidak mendekati obyektif. Berdasarkan beberapa referensi yang telah penulis kaji, maka ada beberapa hal yang menunjukkan keunggulan metode Yūuf al-Qaraḍāīi.

Pertama, metode yang ditawarkan al-Qaraḍ̄āīi tidak hanya teori an sich, tetapi juga disertai dengan aplikasi atas problematika kekinian. Selain itu gagasan solusi diuraikan dengan bijaksana. Seperti halnya ketika membahas tentang wajibnya mengeluarkan zakat untuk saham dan obligasi perusahaan. Tentunya dalam hadis tidak menyebut saham dan obligasi sebagai hal yang wajib untuk dizakati, namun Yusuf alQaraḍāi mengkiaskan saham dan obligasi dengan barang dagangan. ${ }^{41}$

Kedua, metode pemahaman hadis yang ditawarkan Yüuf alQaradââi mampu mengharmonisasikan antara normativitas teks hadis dengan historisitasnya pada konteks sosio-historis komunitas masyarakat muslim setempat. Ketiga, dapat membuka pemikiran masyarakat dunia untuk mengkaji hadis-hadis Nabi sehingga sesuai dengan yang dijalankan Nabi. Keempat, memiliki contoh-contoh hadis yang lengkap dan memiliki penjelasan yang rinci.

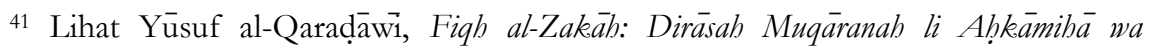
Falsafatihà fì Ḍau' al-Qur'an wa al-Sunah, vol. 1 (Kairo: Maktabah Wahbah, 1994), 553. 
Sedangkan terkait kelemahan yang terdapat dalam metode pemahaman Yúsuf al-Qaraḍāi dapat dituangkan dalam beberapa poin berikut ini: Pertama, metode pertama Yüsuf al-Qaradāāi yang berbunyi "memahami sunah dengan panduan Alquran" tampak menomorduakan hadis. Pandangan al-Qaradāawi seperti itu tidak selamanya dapat diterapkan secara mutlak. Karena terdapat ayat-ayat Alquran yang menjelaskan kesamaan kedudukan antara Alquran dan hadis. Seperti dalam Q.S. An-Nisa' [4]: 80, Q.S. Âli 'Imrān [30]: 31-32, Q.S. al-Ḥashr [59]: 7, Q.S. al-Aḥāab [33]: 36, dan Q.S. al-Nahl [16]: 44. Oleh karena itu, metode yang tepat adalah berbunyi "rela dengan kewajiban mengambil Alquran dan hadis secara bersamaan dalam satu waktu".

Kedua, metode pemahaman yang ditawarkan al-Qaradāāi bukan metode yang bersifat utuh, sehingga belum tentu dapat diaplikasikan untuk semua permasalahan, melainkan hanya kasuistik saja. Seperti metode yang berbunyi "mengetahui alam gaib dan alam nyata", metode ini tidak dapat diaplikasikan ke dalam permasalahan hisab rukyat. Karena hisab rukyat itu sendiri tidak terkait dengan alam gaib maupun alam nyata.

Ketiga, metode yang ditawarkan Yūuf al-Qaraḍ̄āi terkesan bertele-tele (itnab), tidak bisa lebih ringkas (ijaz). Misalnya pada metode kedua yang berbunyi "menghimpun hadis-hadis dalam satu tema" dan metode ketiga yang berbunyi "melakukan kompromi atau tarjih di antara hadis yang bertentangan". Metode kedua dan metode ketiga tersebut menurut hemat penulis dapat diringkas menjadi satu metode, sehingga berbunyi "menghimpun hadis-hadis dalam satu tema dan melakukan kompromi atau tarjih di antara hadis yang bertentangan".

Selain itu ada pula metode yang dapat digabungkan. Seperti yang terjadi pada metode keenam "membedakan antara lafal yang hakikat dan majaz" dan metode ke delapan "memastikan petunjuk lafal-lafal hadis". Menurut penulis, metode keenam itu secara otomatis dapat include pada metode yang kedelapan. Karena ketika mengkaji petunjuk lafal-lafal hadis, secara otomatis di dalamnya juga akan mengkaji status lafal dari sisi hakikah dan majaznya. Keempat, metode pemahaman yang diusung al-Qaraḍ̄āi masih bersifat global, tidak rinci, sehingga dapat menimbulkan salah persepsi. Kelima, terdapat beberapa hadis yang tanpa sanad dan periwayat. 


\section{Daftar Pustaka}

Abdullah, Amin. "Religion, Sicience, and Culture, An Integrated, Interconected Paradigm of Science," dalam Al-Jamiab: Journal of Islamic Studies, Vol. 52, No. 1, (2014).

Ali, Nizar. Memahami Hadis Nabi (Metode dan Pendekatan). Yogyakarta: CESai YPI al-Rahmah, 2001.

Anwar, Syamsul. "Metode Usul Fikih untuk Kontekstualisasi Pemahaman Hadis-hadis Rukyat," dalam Jurnal Tarjib, Vol. 11, No. 1 (2013).

"Problem Penggunaan Rukyat, dalam Rida, dkk., Hisab Bulan Kamariah: Timjauan Syar'i tentang Penetapan Awal Ramadlan, Syawwal dan Dzulbijjah. Yogyakarta: Suara Muhammadiyah, 2012. "Metode Penetapan Awal Bulan Qamariah," dalam Analytica Islamica, Vol. 1, No. 1 (2012).

Azhari, Susiknan. Hisab \& Rukyat Wacana Untuk Membangun Kebersamaan di Tengah Perbedaan. Yogyakarta: Pustaka Pelajar, 2007.

Bayhāqii (al), Abū Bakr Aḥmad b. Ḥusayn b. 'Alì b. Mūsā. Sunan AlKubrā. ed. Muḥammad 'Abd al-Qādir 'Ațā. Makkah: Dar al-Baz, 1994.

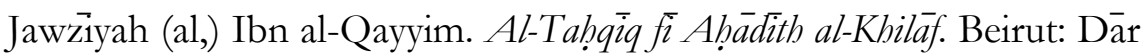
al-Kutub al-'Ilmiyyah, 1994.

Ilyas, Hamim dan Suryadi, Wacana Studi Hadis Kontemporer. Yogyakarta: Tiara Wacana, 2002.

Karatas, Mustafa. "Rereading the Hadith from the Perspective of Observing the Crescent", dalam Ataturk Universitesi Sosyal Bilimler Enstitusu Dergisi, 16, 3, (2012).

Ma'shum. "Metode Abu Dawud dalam Menulis Kitab al-Sunan," dalam Mutawatir: Jurnal Keilmuan Tafisr Hadith, Vol. 1, No. 2 (2011).

Manẓur (ibn), Muhammad. Lisān al-'Arab. Kairo: Dār al-Ma'árif, 1119 $\mathrm{H}$.

Mulyadi, Ach.. "Melacak Geneologi Sistem dan Penerapan Mazhab Hisab Pesantren Karay Ganding Sumenep," dalam Nuansa Jurnal Penelitian Ilmu Sosial dan Keagamaan Islam, Vol. 8, No. 1 (2011).

Nuril Izza, Farah. "Hermeneutika: Arah Baru Interpretasi Hadis (Studi Analisis Pemikiran Yūsuf al-Qardhawi dalam Fatwafatwanya," dalam Komunika, Vol. 8, No. 2 (2014). 
Qaraḍāwi (al), Yüsuf. Madkhāl li Diräsat al-Sharī'ah al-Islämiyah. Kairo: Maktabah Wahbah, 2001. - Al-Fatawāa al-Mu'asirirah. Beirut: Al-Maktab al-Islāmi, 2003. Al-Halàl wa al-Haram fì al-Isläm. Beirut: Dār Maktabat alHilāl, 1990. . Fiqh al-Zakāh: Dirāsah Muqāranah li Aḥkāmihà wa Falsafatihā fì Dau' al-Qur'an wa al-Sunnah. Kairo: Maktabah Wahbah, 1994. Kayf Nata'ämal ma'a al-Sunnah al-Nabawiyah. Kairo: Dār alShurūq, 2004.

Qarā̄ì (al), Shihāb al-Dìn. Al-Furūq: Anwār al-Burūq fì Anwā al-Furūq. ed. Khalili Manșūr. Beirut: Dār al-Kutub al-'Ilmìyah, 1998.

Saputra, Hasep. "Genealogi Perkembangan Studi Hadis di Indonesia," dalam Al Quds Jurnal Studi Alquran dan Hadis, Vol. 1, No. 1 (2017).

Șan'anī (al), 'Abd al-Razzāq. Mușannaf 'Abd al-Razzāq. ed. Habīib alRaḥmān 'Azamì. India: Al-Majlis al-Ilmi, $1403 \mathrm{H}$.

Suryadi. "Kontribusi Studi Hadis dalam Menjawab Persoalanpersoalan Kekinian," dalam Jurnal Studi Ilmu-ilmu Alquran dan Hadis, Vol. 12, No. 2 (2011). "Dari Living Sunah ke Living Hadis," dalam Metodologi Penelitian Living Qur'an dan Hadis. Yogyakarta: Teras, 2007. Teras, 2008.

Shaybah, Abū Bakr b. Abī. Musannaf Abī Shaybah. ed. Kamāl Yūsuf alHüt. Riyad: al-Rushd, $1409 \mathrm{H}$.

Ismail, Muhammad Syuhudi. Metodologi Penelitian Hadis Nabi. Jakarta: Bulan Bintang, 1992.

Wasman. "Hermeneutika Hadis Hukum", dalam Al-Manāhij Jurnal Kajian Hukum Islam, Vol. 8, No. 2 (2014). 